This is the post-peer reviewed author's manuscript published in: Jakubowski, A. (ed.) Cultural Rights as Collective Rights. Leiden, Netherlands : Brill, 2016. doi: 10.1163/9789004312029_015.

\title{
CHAPTER 13 Collective Cultural Claims before the International Court of Justice
}

Eleni Polymenopoulou

\section{Introduction}

In the aftermath of the Second World War, when the system of the United Nations was created, granting rights to collectivities was not a United Nations priority. Collective rights, and, a fortiori, the right of groups 'to protect and develop their own particular cultural characteristics ${ }^{1}$ were, at that time, seen as a peril to the establishment of the international human rights system. 'Groups' meant division, discord, conflict, and disparity. Ultimately, they meant war. Hence, affirming different cultural identities with an imprecise scope, nature and boundaries, and discriminating among individuals on the basis of their belonging to a group, was considered something inherently contradictory to human rights. In addition, as the former Director-General of UNESCO Koichiro Matsuura observes, the meaning of the word 'culture' back in the 1945 would refer to arts and the letters, rather than to a group right 'to be different' ${ }^{2}$

In light of these observations, when the International Court of Justice (ICJ) was established, ${ }^{3}$ its mandate did not explicitly include minority and group rights issues, as did that of its predecessor, the Permanent Court of International Justice ('PCIJ'). The latter, in addition to

\footnotetext{
${ }^{1}$ Douglas Sanders, 'Collective Rights' (1991) 13 HRQ 368, 369.

${ }^{2}$ Koichiro Matsuura, 'L’enjeu culturel au cœur des relations internationales' (2006) 4 Politique Étrangère 1045 , 1048.

${ }^{3}$ Charter of the United Nations and Statute of the International Court of Justice, signed on 26 June 1945, entered into force on 24 October 1945), 1 UNTS XVI, amended in 1963 (557 UNTS 143), in 1965 (638 UNTS 308), and in 1971 (892 UNTS 119).
} 
its general competence to consider any legal question that the states would bring to its attention, ${ }^{4}$ had explicit jurisdiction over the numerous minority treaties that existed under the regime of the League of the Nations. ${ }^{5}$ Not surprisingly, this then- World Court issued numerous opinions and judgements on cases and issues related to minority rights, and several of its findings constitute a source of inspiration in minority rights enforcement and adjudication even today. For instance, in the case of Minority Schools of Upper Silesia (1928), the PCIJ discussed the question of the admission criteria of children speaking languages other than the official Polish language to the minority schools of Upper Silesia and the subsequent rights of their parents to choose the language of instruction-noting that 'every national has the right freely to declare, according to his conscience and on his personal responsibility, that he does or does not belong to a racial, linguistic or religious minority, and to declare what is the language of a pupil or child for whose education he is legally responsible. ${ }^{6}$ In the case of Greco-Bulgarian "Communities” (1930), ${ }^{7}$ it gave an interesting

\footnotetext{
${ }^{4}$ Arts 13 and 14 of the Covenant of the League of the Nations, adopted on 28 June 1919, entered into force on 10 January 1920, 225 Parry's CTS 195, and Art. 36 of the Statute of the PCIJ, Protocol of 16 December 1920, amended 14 September 1929; available at <http://www.worldcourts.com/pcij/eng/documents/1920.12.16_statute.htm> accessed on 15 December 2015. ${ }^{5}$ See 'Documents presented by the Advisory Committee of Jurists to the Committee relating to existing plans for the establishment of a Permanent Court of International Justice (1920)' 109 (ch VII on the 'Competence of the Court as the Ultimate Tribunal of Civilisation').

${ }^{6}$ Rights of Minorities in Upper Silesia (Minority Schools), Judgment of 26 April 1928, PCIJ Ser. A, No. 15, Fourth Annual Report of the PCIJ (15 June 1927-15 June 1928), Ser. E, No. 4, 210, reprinted in UN Doc. ST/LEG/SER.F/1/Add.4 (2012), 141, at 145. Cfr. German Minority Schools in Upper Silesia, Advisory Opinion of 15 May 1931, PCIJ Ser. A/B, No. 40, Seventh Annual Report of the PCIJ (15 June 1930—15 June 1931), Ser. E, No. 7, 261, reprinted in UN Doc. ST/LEG/SER.F/1/Add.4 (2012), 223.
} 
description of the characteristics of a 'community', which encompassed religion, language and tradition, along with the 'sentiment of solidarity with a view to preserving their traditions', ${ }^{8}$ and noted, memorably, that the existence of these communities was 'a question of fact not dependent of any regulation resulting from the local law'.${ }^{9}$ Even more notably, in the advisory opinion regarding the Minority Schools in Albania $(1935)^{10}$ it employed a broad reading of Albania's international obligations with respect to the religious and educational autonomy enjoyed by the Greek minority in Albania. ${ }^{11}$ According to the PCIJ, the League of Nations' minority legal regime provided for substantial equality, since not only did it embrace the principle of "perfect equality between nationals belonging to the minority and other nationals', but further, 'grant[ed] to minorities of suitable means for the preservation of their racial peculiarities, their traditions and their characteristics'. ${ }^{12}$

\footnotetext{
${ }^{7}$ Greco-Bulgarian “Communities”, Advisory Opinion of 31 July 1930, PCIJ Ser. B, No. 17, Seventh Annual Report of the PCIJ (15 June 1930-15 June 1931), Ser. E, No. 7, reprinted in UN Doc. ST/LEG/SER.F/1/Add.4 (2012), 203.

${ }^{8}$ Ibid 205: 'The criterion for determining what is a community $(\ldots)$ is the existence of a group of persons living in a given country or locality having a race, religion, language and traditions of their own, and united by this identity of race, religion, language and traditions in a sentiment of solidarity with a view to preserving their traditions, maintaining their form of worship, ensuring the instruction and up-bringing of their children in accordance with the spirit and traditions of their race and mutually assisting each other'.

${ }^{9}$ Ibid.

${ }^{10}$ Minority Schools in Albania, Advisory Opinion of 6 April 1935, PCIJ Ser. A/B, No. 64, Eleventh Annual Report of the PCIJ (15 June 1934-15 June 1935), Ser. E, No. 11, 214, reprinted in UN Doc.
} ST/LEG/SER.F/1/Add.4 (2012), 348.

${ }^{11}$ See Declaration concerning the Protection of Minorities in Albania, signed on 2 October 1921, 9 LNTS 175.

${ }^{12}$ Minority Schools in Albania (n 10) 351. 
The assumption that the ICJ is, generally, not competent to address collective cultural claims merely because it does not have an explicit mandate to do so is misleading. In fact, the Court is competent to deal with any sort of dispute between states, as well as with the interpretation of any United Nations (UN) Treaty. ${ }^{13}$ This means that the examination of collective cultural claims is a priori not excluded from the Court's competence. And indeed, such issues may be examined by the Court, either as legal issues in the framework of an inter-state complaint, or as features of an advisory opinion. It seems that only practical impediments are currently restricting the actual number of cases touching upon questions of collective rights. First of all, there is the fact that the ICJ Statute does not recognise standing for any collective entities other than States parties to the Charter. ${ }^{14}$ Therefore, minorities, or indigenous peoples, even though they are specially singled out in UN treaties as collectivities and would be potentially interested in raising collective cultural issues before the Court, are excluded from standing. ${ }^{15}$ The second and corollary impediment is one of likelihood, or more accurately the lack thereof. While the jurisdiction of the Court indeed 'comprises all cases which the parties refer to it and all matters specially provided for in the Charter of the United Nations or in treaties and conventions in force, ${ }^{, 16}$ it seems quite unlikely that the interests of collectivities to

\footnotetext{
${ }^{13}$ Art. 36(2) of the ICJ Statute; available at < http://www.icj-cij.org/documents/?p1=4\&p2=2> accessed on 15 December 2015 .

${ }^{14}$ Art. 34(1) of the ICJ: 'Only states may be parties in cases before the Court'.

15 Thus, a United Nations information leaflet notes that 'the International Court of Justice (...) has a limited role in considering human rights violations. The Court considers only disputes between governments and does not receive submissions from individuals, it is unlikely that indigenous peoples will have occasion to work with the International Court of Justice', see Office of the United Nations High Commissioner for Human Rights (OHCHR), 'Indigenous Peoples and the United Nations System: An overview'; available at < http://www.ohchr.org/Documents/Publications/GuideIPleaflet1en.pdf> accessed on 29 January 2016.

${ }^{16}$ Art. 36(1) of the ICJ Statute.
} 
preserve their cultural identities would either coincide or significantly affect the interests of a state to the point that the latter would take such a case to the ICJ.

Yet, the international law developments of the last decade have also had an impact on the ICJ case law. As the highest World jurisdiction, the ICJ does not, and cannot, operate in a vacuum. Therefore, it cannot remain indifferent to the expansion of debates on culture and cultural rights, ${ }^{17}$ and the subsequent increase of their justiciability, either by means of recognition in regional and international instruments (including soft law instruments), ${ }^{18}$ or

\footnotetext{
${ }^{17}$ See generally, Silvia Borelli and Federico Lenzerini (eds), Cultural Heritage, Cultural Rights, Cultural Diversity: New Developments in International Law (Nijhoff, 2012).

${ }^{18}$ As an indication only, see the establishment of the Optional Protocol to the International Covenant on
} Economic, Social and Cultural Rights (UNGA Res.63/117, adopted on 10 December 2008, entered into force 5 May 2013, UN Doc. A/RES/63/117); the proclamation of the UN Declaration on the Rights of Indigenous Peoples (UNDRIP; UNGA Res. 61/295, adopted on 13 September 2007, UN Doc. A/RES/61/295), in particular Art. 8 regarding their right 'not to be subjected to forced assimilation or destruction of their culture', and the corresponding para 2 regarding states' obligations to 'provide effective mechanisms for prevention of, and redress for: (a) Any action which has the aim or effect of depriving them of their integrity as distinct peoples, or of their cultural values or ethnic identities (...)', and Art. 11 on their right to practise and revitalize their cultural traditions and customs, and Art. 12 on their right to 'manifest, practise, develop and teach their spiritual and religious traditions, customs and ceremonies'; the proposed Nordic Saami Convention to be adopted by Norway, Sweden and Finland as intended to 'affirm and strengthen such rights of the Saami people that are necessary to secure and develop its language, its culture, its livelihoods and society, with the smallest possible interference of the national borders' (Art. 1) (available at <https://www.regjeringen.no/globalassets/upload/AID/temadokumenter/sami/sami_samekonv_engelsk.pdf> accessed on 15 December 2015); Convention on the Protection and Promotion of the Diversity of Cultural Expressions (adopted on 20 October 2005, entered into force 18 March 2007, 2440 UNTS 311), for example Art. 5(2), which states that 'when a Party implements policies and takes measures to protect and promote the 
enforcement by domestic, ${ }^{19}$ regional $^{20}$ and other international mechanisms ${ }^{21}$ of human rights protection. In recent years a number of Judges with significant experience in human rights

diversity of cultural expressions within its territory, its policies and measures shall be consistent with the provisions of this Convention'. See also Chapter 11 by Francesco Francioni in this volume.

${ }^{19}$ See, for example, Malcolm Langford, 'Domestic Adjudication and Economic, Social and Cultural Rights: A Socio-Legal Review' (2009) 6 SUR International Journal of Human Rights 91.

${ }^{20}$ See the pioneering role of the Inter-American Court of Human Rights in promoting peoples' rights, inter alia in the cases: Mayagna (Sumo) Awas Tigni Community v Nicaragua, Judgment of 31 August 2001, 79 IACtHR

(Ser. C), No. 79 (2001); Yakye Axa Indigenous Community v Paraguay, Judgment of 17 June 2005, IACtHR (Ser. C), No. 125 (2005); Saramaka People v Suriname, Judgment of 28 November 2007, IACtHR (Ser. C), No. 172 (2007). Kichwa Indigenous People of Sarayaku v Ecuador, Judgment of 27 June 2012, IACtHR (Ser. C), No. 245 (2012). Further read Chapter 10 by Kristin Hausler in this volume. See also the recent cases before the African Commission on Human and Peoples' Rights: Social and Economic Rights Action Centre and the Centre for Economic and Social Rights v Nigeria (Ogoni case), AfCHPR, Comm. No. 155/96, 27 May 2002; Centre for Minority Rights Development and Minority Rights Group (on behalf of Endorois Welfare Council) v Kenya, AfCHPR, Comm. No. 276/03, 4 February 2010. Further read Chapter 9 by Folarin Shyllon in this volume. Even the European Court of Human Rights has made contributions to the enhancement of collective rights over the last few years through a dynamic interpretation of the European Convention (ECHR); see, for example ,the cases regarding non-segregation in education for Roma minorities: Oršuš and Others v Croatia, Application No. 15766/03, Judgment of the Grand Chamber of 16 March 2010, ECHR (2010), and D.H. and Others v the Czech Republic, Application No. 57325/00 Judgment of the Grand Chamber of 13 November 2007, ECHR 2007-IV. Also see Tănase v Moldova, Application No. 7/08, Judgment of the Grand Chamber of 27 April 2010, ECHR (2010) and Tunceli Kültür ve Dayanışma Derneği v Turkey, Application No. 61353/00, 10 October 2006, ECHR (2010). Cfr Chapter 4 by Yvonne Donders in this volume, at Section 5.2.

${ }^{21}$ Issues related to cultural heritage protection have been examined in the context of prosecutions and trials before both the International Criminal Tribunal for the Former Yugoslavia (ICTY), the Human Rights Chamber for Bosnia and Herzegovina, as well as the International Criminal Court (ICC), where it has also been noted that the destruction of cultural heritage is a war crime according to both the ICTY and the ICC statute. Additionally, the Rome Statute (Art. 7, para 1h] explicitly establishes that persecution against any identifiable group or 
adjudication have joined the Court. ${ }^{22}$ It seems that this evolution affects the interpretation of international law by the Court. Hence, the Court has expanded its jurisdiction in a way so as to progressively substantiate its contributions to human rights protection. ${ }^{23}$ This is indeed noteworthy since the Court is the highest authority on the interpretation and application of international law.

collectivity on, inter alia, ethnic, cultural and religious grounds is a crime against humanity 'when committed as part of a widespread or systematic attack directed against any civilian population'. Statute of the International Criminal Court (State of Rome), adopted on 17 July 1998, entered into force on 1 July 2002, UN Doc.

A/CONF.183/9, 2187 UNTS 90. Further read Federico Lenzerini, ‘The Role of International and Mixed Criminal Courts in the Enforcement of International Norms Concerning the Protection of Cultural Heritage' in Francesco Francioni and James Gordley (eds), Enforcing International Cultural Heritage Law (OUP, 2013) 40. ${ }^{22}$ Current Judges of the Court include Judge Antônio Augusto Cançado Trindade, former President of the InterAmerican Court of Human Rights; Judge Abdulqawi Ahmed Yusuf, former Legal Adviser to the UNESCO; Christopher Greenwood and Ronny Abraham (President of the Court since 2015), who both have been councils inter alia before the European court of Human rights. Other individuals with significant human rights expertise have also been members of the Court in the last decade, including most notably Rosalyn Higgins (1995-2009 and President of the Court during 2005-2009), Pieter Kooijmans (1997-2006), Thomas Buergenthal (20002010) and Bruno Simma (2003-2012). On this point, see Rosalyn Higgins, 'Human Rights in the International Court of Justice' (2007) 20 Leiden Journal of International Law 745, 746.

${ }^{23}$ As an indication only, cases with human rights interest include, for example, Ahmadou Sadio Diallo (Republic of Guinea v Democratic Republic of the Congo), Judgment of 24 May 2007, ICJ Reports 2007, 582; Armed Activities on the Territory of the Congo (Democratic Republic of the Congo v Uganda), Judgment of 19 December 2005, ICJ Reports 2005, 168. See generally Higgins 'Human Rights' (n 22) 745ff; also see Gentian Zyberi, 'The Development and Interpretation of International Human Rights and Humanitarian Law Rules and Principles through the Case-Law of the International Court of Justice' (2007) 25 Netherlands Quarterly of Human Rights 117. 


\section{The ICJ's Cautious Approach to the Recognition of Collective Cultural Claims}

The increased importance attributed to human rights does not mean that minority rights and indigenous peoples' claims are now reaching the Court. States are still the only actors to have locus standi before the Court, ${ }^{24}$ and an actio popularis brought before the Court is still prohibited. ${ }^{25}$ Nevertheless, in a number of cases collective cultural claims may reach the Court through states' submissions. The following situations may be distinguished: 1) national cultural claims advanced by states; 2) minority cultural claims advanced by states; 3 ) indigenous peoples' cultural claims advanced by states.

\subsection{National Cultural Claims Advanced by States}

It may happen that a state advances collective cultural claims as its own national claim. Such a situation may arise when self-identified nation-states enjoying a high percentage of ethnic, cultural and religious homogeneity advance collective cultural claims in the name of the nation as a whole.

\footnotetext{
${ }^{24}$ For the views of some authors voicing the necessity for reform of the ICJ Statute, see, for example, Paul Magnarella, 'Expanding the Role of the International Court of Justice to Resolve Interethnic Conflict and Protect Minority Rights' (1993) Journal of Transnational Law \& Policy 103; also see James Anaya, 'The Capacity of International Law to Advance Ethnic or Nationality Rights Claims' (1990) 75 Iowa Law Review 837.

${ }^{25}$ South West Africa Cases (Ethiopia v South Africa; Liberia v South Africa), Second Phase, Judgment of 18 July 1966, ICJ Reports 1966, 6, para 88: 'the argument amounts to a plea that the Court should allow the equivalent of an actio popularis, or right resident in any member of a community to take legal action in vindication of a public interest. But although a right of this kind may be known to certain municipal systems of law, it is not known to international law as it stands at present: nor is the Court able to regard it as imported by the "general principles of law" referred to in Article 38, paragraph 1 (c), of its Statute.'
} 
Such an issue has arisen, for instance, in the context of the Republic of Macedonia v Greece case (2011). ${ }^{26}$ The case concerned Greece's objection to Macedonia's admission to the NATO, and its failure to comply with the relevant Interim accord; yet, in substance, it concerned the use of the name 'Macedonia', to which both Parties had legal interests in (this was the main reason the Greek objected to the Applicant's membership). Greece's allegations about Macedonia's failure to comply with its obligations under the Interim Accord included allegations about its illicit use of historical or cultural symbols. In particular, Greece, a selfidentified nation-state with a high percentage of ethnic, cultural and religious homogeneity, highlighted that Macedonia had breached its obligation emanating from the Interim accord in a variety of ways, including allowing to its army to use the Macedonian symbol on its flags, ${ }^{27}$ and 'by issuing stamps, erecting statues and renaming the airport of the capital'. ${ }^{28}$ The Court was not persuaded by Greece's arguments, that is, by its objection to Macedonia's admission to NATO was justified as a response to material breaches of the Interim Accord (even though

\footnotetext{
${ }^{26}$ Application of the Interim Accord of 13 September 1995 (the former Yugoslav Republic of Macedonia $v$ Greece), Judgment of 5 December 2011, ICJ Reports 2011, 644.

${ }^{27}$ Ibid paras 154-59, regarding the respondent's alleged breach of Art. 7(3) of the Interim Accord, which provided that: 'if either Party believes one or more symbols constituting part of its historic or cultural patrimony is being used by the other Party, it shall bring such alleged use to the attention of the other Party, and the other Party shall take appropriate corrective action or indicate why it does not consider it necessary to do so'.

${ }^{28}$ Ibid paras 148-53, regarding the respondent's alleged breach of Art 7(2) of the Interim Accord, which provided that: 'Upon entry into force of this Interim Accord, the Party of the Second Part shall cease to use in any way the symbol in all its forms displayed on its national flag prior to such entry into force.'
} 
it found one exceptional use of the name by Macedonia, in 2004, four years prior Greece's objection). ${ }^{29}$ Interestingly, Judge Roucounas, sitting as an ad hoc judge for Greece, dissented, asserting that the Court should not have taken jurisdiction over the case precisely because important cultural, historical, and national issues were at stake. ${ }^{30}$

In the past, in the context of colonisation and territorial mandates, it also happened that states would advance cultural claims (claims to education, religion, language, protection of heritage and cultural identity etc.) as their own peoples' claims, with respect to the coloniser or the policies of the mandate holder. Here one may consider, in particular, the South West Africa judgement, ${ }^{31}$ where several claims of the previously colonised Ethiopia and Liberia were of a 'cultural' nature. ${ }^{32} \mathrm{~A}$ key issue in this case was to consider the concept of 'civilisation' and examine whether the interpretation of the relevant colonial treaties 'intended to give juridical expression to the notion of the 'sacred trust of civilization'. Despite its expression of intention to explore the question further, ${ }^{33}$ the Court failed to address the concept of

\footnotetext{
${ }^{29}$ Ibid paras 161-62.

${ }^{30}$ Dissenting opinion of ad hoc Judge Roucounas, paras 23-4: 'by upholding the Applicant's claim and finding that it has jurisdiction, the Court has involved itself in the intricacies of the Parties' political and cultural relations with each other and with the international organization in question (...) a composite reading of the Accord would have enabled the Court to discern in the text the need to take account of the historical and cultural elements which loom large over the case and to distance itself from the reactions, both political and on the popular psychological level, which are liable to be aroused on either side by the Judgment'.

${ }^{31}$ South West Africa, Judgment of 18 July 1966 (n 25).

${ }^{32}$ Memorials of Liberia and Ethiopia, para 4, cited in the Judgment (at 12). The claims were mostly related to the economic, political, social and educational policies applied in the claimants' territories, since the Applicants had submitted to the Court that the mandate power had 'failed to promote to the utmost the material and moral well-being and social progress of the inhabitants of the Territory'.

${ }^{33}$ Ibid para 51.
} 
'civilization' from a 'culturally sensitive' perspective, contenting itself with stating that 'as such, it constitutes a moral ideal given form as a juridical régime in the shape of that system' and that 'it is necessary not to confuse the moral ideal with the legal rules intended to give it effect'. ${ }^{34}$

\subsection{Minority Cultural Claims Advanced by States}

The second identifiable situation in which a state may raise cultural claims concerns instances in which a state has interests in raising the issue of minority rights protection. Such situation may arise, for example, in the case of an on-going ethnic or religious conflict, or when a minority group sees the right to its cultural heritage being violated.

The question of cultural genocide, that is, the full and complete destruction of a group's cultural identity as part of a policy of ethnic cleansing ${ }^{35}$ naturally comes up as the first example of such situation. ${ }^{36}$ This issue has been raised before the ICJ in two cases whereby

\footnotetext{
${ }^{34}$ Ibid para 52.

${ }^{35}$ At the international level, the issue has been extensively discussed when drafting both the Convention on the Prevention and Punishment of the Crime of Genocide (UNGA Res. 260A(III), adopted on 9 December 1948, entered into force on 12 January 1951, 78 UNTS 277) and the Universal Declaration of Human Rights (UNGA Res 217 A(III), adopted on 10 December 1948, UN Doc A/810, 71): in the former, the Sixth Committee's travaux preparatoires explicitly excluded cultural genocide from the list of punishable acts, while in the latter, an additional provision related to minority rights - which could, eventually, provide for protection against cultural genocide - did not attain a sufficient number of voters. See 'Report of the International Law Commission on the work of its Forty-eighth Session' (1996) 2(2) Yearbook of the International Law Commission 45-46, para. 12. See also Johannes Morsink, 'Cultural Genocide, the Universal Declaration, and Minority Rights’ (1999) 21 HRQ 1016, 1051.

${ }^{36}$ For a comprehensive analysis of this topic see Chapter 14 by Elisa Novic in this volume.
} 
proceedings were initiated against Serbia - the Bosnian Genocide case, which led to a 2007 judgement, ${ }^{37}$ and the Croatia $v$ Serbia case, which was decided by the ICJ in $2015 .{ }^{38}$ In the first, Bosnia and Herzegovina complained about Serbian attempts to eradicate 'all traces of the culture of the protected group through the destruction of historical, religious and cultural property' ${ }^{39}$; the ICJ held that such a crime could not be recognized as punishable under the Genocide Convention, even though it did recognize that there was 'conclusive evidence of the deliberate destruction of the historical, cultural and religious heritage of the protected group during the period in question' ${ }^{40}$ In the second, Croatia submitted to the Court that the looting of its cultural property amounted to a breach of the Convention and to the destruction of the Bosnian Muslim cultural identity, requesting 'to return to the Applicant any items of cultural property within its jurisdiction or control which were seized in the course of the genocidal acts for which it is responsible' ${ }^{41}$ The question came again to examination since Croatia, just like Bosnia, claimed before the Court that it perceived the destruction of its cultural heritage as part of a broader plan aiming at the extinction of the Croatians as an ethnic group - something that would fall, by implication, under the Genocide Convention. The Court citing the judgement in the Bosnian genocide case, found once again that the act of

\footnotetext{
${ }^{37}$ Case Concerning Application of the Convention on the Prevention and Punishment of the Crime of Genocide (Bosnia and Herzegovina v Serbia and Montenegro), Judgment of 26 February 2007, ICJ Reports 2007, 43. ${ }^{38}$ Application of the Convention on the Prevention and Punishment of the Crime of Genocide (Croatia $v$ Serbia), Judgment of 3 February 2015; available at <http://www.icj-cij.org/docket/files/118/18422.pdf> accessed on 15 December 2015.

${ }^{39}$ Bosnia and Herzegovina v Serbia and Montenegro, Judgment of 26 February 2007 (n 37) para 320.

${ }^{40}$ Ibid para 344.

${ }^{41}$ Croatia v Serbia, Judgment of 18 November 2008 (Preliminary Objections), ICJ Reports 2008, 412, Preliminary Objections, 18 November 2008, paras 21.2(c), 140.
} 
genocide was not substantiated, recognizing however, that such attacks on cultural and religious property may, eventually, establish 'genocidal intent'. ${ }^{42}$

A second example of protection of minority interest by a state can arise when the latter acts as a kin state, with interests in protecting the rights of its own ethnic and national minorities residing in a neighbouring state. The Case Concerning Application of the International Convention on the Elimination of All Forms of Racial Discrimination, ${ }^{43}$ brought by Georgia against Russia, may serve as a good illustration of a state bringing collective cultural claims to the ICJ. The case concerned the disputes that took place between Russia and Georgia in the period from 1992 to 2008, and which affected the Georgian minorities living in Russia (Abkhazia and South Ossetia). Georgia's complaints ${ }^{44}$ were largely based on cultural collective claims. The applicant state in fact, not only complained about racial segregation and policies inciting to hatred; it further discussed in its memorial questions of assimilation (what Georgia saw as a generalised plan to create 'ethnically pure territories aligned with the Russian Federation') and racial discrimination to the point of constituting a policy of ethnic cleansing, that is, the destruction of the 'Georgian culture and identity by discriminatory legislation and other means'. ${ }^{45}$ The Court nevertheless declared itself unable to examine the claim further due to lack of competence, since Georgia had not attempted to resolve the issues through negotiations according to its obligations under ICERD, prior reaching the Court.

\footnotetext{
${ }^{42}$ Croatia v Serbia, Judgment of 3 February 2015 (merits) (n 38) para 142.

${ }^{43}$ Georgia v Russian Federation, Judgment of 1 April 2011 (preliminary objections), ICJ Reports 2011, 70.

${ }^{44}$ Based on Arts. 2 (1)(a), 2 (1)(b), 2 (1)(d), 3 and 5 of the International Convention on the Elimination of All Forms of Racial Discrimination ('ICERD'), UNGA Res. 2106(XX), adopted on 21 December 1965, entered into force on 4 January 1969, 660 UNTS 195.

${ }^{45}$ Georgia v Russian Federation, Memorial of Georgia, Vol.1, 2 September 2009, particularly paras 2.40-2.41.
} 


\subsection{Indigenous Peoples' Cultural Claims Advanced by States}

Thirdly, states may also advance the cultural interests of indigenous peoples as an issue to be considered by the ICJ, if such is deemed beneficial to their own interests. Such a situation may occur, for example, with respect to the interpretation of the uti possidetis juris principle. $^{46}$

The ICJ, despite initially recognising that uti possidetis's precise function is to limit selfdetermination claims, ${ }^{47}$ has however admitted some flexibility in its application. It has therefore observed that the uti possidetis does not necessarily entail that the boundaries fixed by Treaty on a certain critical date are 'frozen' for an indeterminate period of time, and that eventually the doctrines of acquiescence or recognition, or some other legal principle such as, for example, prescription may come into play. ${ }^{48}$ Consequently, a state would have legitimate

${ }^{46}$ Uti possidetis, just like terra nullius, is a judicial construction borrowed from Roman private law, and traditionally perceived as hostile to collective rights, since its main function is to delineate State boundaries (as demarcated by Western colonisers) at the expense of peoples' rights to self- determination and land rights. See Malcolm Shaw, 'Peoples, Territorialism and Boundaries' (1997) 8 EJIL 478, 481 and Malcolm Shaw, 'The Heritage of States: The Principle of Uti Possidetis Juris Today' (1996) BYIL 97, 98; also see Joshua Castellino, 'Territorial Integrity and the "Right" to Self-Determination: An Examination of the Conceptual Tools’ (2008) 33 Brooklyn Journal of International Law 499, 502.

${ }^{47}$ See Frontier Dispute (Burkina Faso v Republic of Mali), Judgment of 22 December 1986, ICJ Reports 1986, 554, para 26. In this judgment the Court explicitly clarified that newly autonomous states would need 'to take account of it in the interpretation of the principle of self-determination of peoples' (para 25); on this point, see Shaw 'Peoples, Territorialism and Boundaries' (n 46) 481.

${ }^{48}$ Case Concerning The Land, Island and Maritime Frontier Dispute (El Salvador v Honduras: Nicaragua Intervening), Judgment of 11 September 1992, ICJ Reports 1992, 351, para 67: 'a later critical date clearly may 
reasons to claim sovereignty over a territory, as long as it could prove that the uti possidetis could be qualified. And indeed, newly independent states, in order to demonstrate a manifestation of territorial sovereignty, have sometimes used - or misused - the fact of the presence of inhabitants of a certain territory, despite their lack of possession of any relevant title. ${ }^{49}$ Most commonly, these inhabitants are indigenous peoples, even though they are not referred to as such (in states' submissions, as in the Court's judgements, phrases such as 'communities' and 'populations' are generally preferred). As to the Court's consideration of the states' positions, a distinction should be made between advisory opinions and contentious jurisdiction.

\section{a) Indigenous peoples' cultural claims advanced by States in the context of the Court's contentious jurisdiction}

In the context of advisory opinions, the Court has been somewhat more generous in recognising cultural aspects of collective claims (such as claims to self-determination). Yet, here again it has been cautious about making assumptions that extend its jurisdiction to questions which have not been asked.

arise, for example, either from adjudication or from a boundary treaty (...) if the uti possidetis juris position can be qualified by adjudication and by treaty, the question then arises whether it can be qualified in other ways, for example, by acquiescence or recognition. There seems to be no reason in principle why these factors should not operate, where there is sufficient evidence to show that the parties have in effect clearly accepted a variation, or at least an interpretation, of the uti possidetis juris position'.

${ }^{49}$ See The Minquiers and Ecrehos Case (France v United Kingdom), Judgment of 17 November 1953, ICJ Reports 1953, 47, at 57: 'what is of decisive importance, in the opinion of the Court, is not indirect presumptions deduced from events in the Middle Ages, but the evidence which relates directly to the possession of the Ecrehos and Minquiers groups.' 
In the Land and maritime boundary between Cameroon and Nigeria, ${ }^{50}$ one of the arguments that Nigeria used to entrench its territorial sovereignty over the Bakassi Peninsula and certain Lake Chad villages (mostly fishing villages) was the historic consolidation of its title over the disputed areas and the acquiescence of Cameroon. The presence of indigenous peoples (Calabar people, according to Nigeria) ${ }^{51}$ and their 'exclusive association' with the Nigerian State, ${ }^{52}$ was therefore a crucial point of the argument. Hence Nigeria, in its submissions to the Court, discussed 'the attitude and affiliations of the population of Darak and the other Lake Chad villages[...]' and the 'existence of historical links with Nigeria in the area', 53 extensively describing these communities' culture - particularly their educational system, their religious institutions, and their traditional way of life (which included subsistence agriculture and fishing, as well as the maintenance of the system of traditional chiefs - the 'Kings and Chiefs of Old Calabar'). ${ }^{54}$ In contrast, Cameroon highlighted the economic considerations of Nigeria in claiming the disputed territory, pointing out the natural resources, particularly oil and halieutic profits, ${ }^{55}$ and explained that the argument regarding the presence of peoples on the islands of Lake Chad was particularly misleading given the

\footnotetext{
${ }^{50}$ Land and Maritime Boundary between Cameroon and Nigeria (Cameroon v Nigeria: Equatorial Guinea intervening), Judgment of 10 October 2002, ICJ Reports 2002, 303.

${ }^{51}$ Even though throughout the memorial they are rather mentioned as 'inhabitants', and in the Judgment as ‘communities', see Cameroon v Nigeria, Judgment of 10 October 2002 (n 50) para 218.

${ }^{52}$ Cameroon v Nigeria, Counter-Memorial of the Federal Republic of Nigeria, Vol. 1 (Chapters 1-11), 21 May 1999, 432, para 17.71 (conclusions). The Nigerian claims were therefore based on a historical consolidation of title and peaceful possession.

${ }^{53} \mathrm{Ibid}, 196 \mathrm{ff}$. (the existence of legal ties of a 'traditional, administrative, economic and social' nature).

${ }^{54}$ Ibid, Chapters 9-10 of the Counter-Memorial, in which Nigeria attempts to demonstrate the historic consolidation of its title.
}

${ }^{55}$ Cameroon v Nigeria, Cameroon's Memorial, 16 March 1996, 23, paras 340-41 (available only in French). 
increasing problem of dryness in the area. ${ }^{56}$ The Court did not consider the arguments related to the presence of 'communities' and indigenous peoples in the case, since Cameroon already possessed title. The Court found that there was no Nigerian title capable of being confirmed subsequently by 'long occupation' (only titles concluded between Nigeria and the indigenous chiefs), and therefore the argument of historic consolidation could not stand as such.

Regarding the claim on education authorities (and the religious schools in particular), the Court again noted that these were effectivités, not sufficient to reverse the established title of Cameroon. ${ }^{57}$

The Territorial Dispute case (1994) between Libya and Chad ${ }^{58}$ was a similar case involving sovereignty over the - rich in petrol - Aouzou Strip. One of the main claims of Libya was that there existed 'a community of title between the title of the indigenous peoples, and the rights and titles of the Ottoman Empire, passed on to Italy in 1912 and inherited by Libya in 1951'. ${ }^{59}$ Akin to Nigeria, Libya referred to the indigenous and tribal groups presence on the disputed territory, whose conduct was equally crucial for the outcome of the dispute, ${ }^{60}$ in order to demonstrate its sovereignty over the territory. In its memorial submitted to the Court,

\footnotetext{
${ }^{56}$ Ibid 23-4, para 341 (available only in French: 'Quant au Lac Tchad, il est en voie d'assèchement de et les eaux du lac se sont pratiquement retirées du Nigeria, dont les populations se trouvent, de ce fait, privées de leurs ressources halieutiques traditionnelles').

${ }^{57}$ Cameroon v Nigeria Judgment of 10 October 2002 (n 50) para 223 : ' [...] those precedents are therefore not relevant. The legal question of whether effectivités suggest that title lies with one country rather than another is not the same legal question as whether such effectivités can serve to displace an established treaty title'.

${ }^{58}$ Territorial Dispute (Libyan Arab Jamahiriya v Chad), Judgment of 3 February 1994, ICJ Reports 1994, 6.

${ }^{59}$ Ibid 13, para 17 (section iv).

${ }^{60}$ Ibid 12, para 17: 'In the light of the conduct of the parties or other parties, or of the political, secular or religious forces, whose conduct bears on the rights and titles claimed by the Parties, and of the conduct of the indigenous peoples whose territories are the subject of this dispute (...)'.
} 
it extensively discussed these peoples' and groups' origin, numbers and location, as well as their modus vivendi, ${ }^{61}$ explaining how they were led by the Senoussi order and were under their control and protection prior to independence. Hence, crucial to Libya's argumentation were the indigenous and tribal traditional ways of life, trading patterns, caravan and nomadic routes, and religious and educational institutions that were developed in the early twentieth century, such as the Zawiyas, ${ }^{62}$ together with the demonstration of, inter alia, their cultural and religious ties with the central Libyan authority. ${ }^{63}$ Once again however the Court, given the existence of a Treaty, found 'little point in considering what was the pre-1919 situation, in view of the fact that the Anglo-French Convention of 8 September 1919 determined the precise end-point of the line in question [... $]^{64}$; and ruled that the fact that the Treaty had already delineated the boundaries between the two states 'renders it unnecessary to consider the history of the "Borderlands" claimed by Libya on the basis of title inherited from the

\footnotetext{
${ }^{61}$ Libyan Arab Jamahiriya v Chad, Memorial submitted by the Great Socialist People's Libyan Arab Jamahiriya (Libya's Memorial), 26 August 1991, Part III, Ch. 2, entitled 'The indigenous peoples', 38-54; and Part IV, entitled 'The Impact of colonial expansion on the indigenous peoples: the resulting modus vivendi', 69-84.

${ }^{62}$ The zawiyas were the 'urban centres' of that time, typical Islamic lodges, functioning both as religious schools and monasteries). Libya considers the existence of zawiyas as 'instruments' of its authority; see, ibid, at 44, Section 3.44(a) entitled 'The Role of the Zawiva as an Instrument of Senoussi Authority'; and 3.46, entitled 'Senoussi Authoritv and Leadershia in the Libva-Chad Borderland', with regard to zawivas ('built at tribal centres, or at watering places and junctions on the trade and pilgrim routes, (which) served as monasteries, schools, hostels, sources of advice and mediation and, in due course, as administrative centres').

${ }^{63}$ Libyan Arab Jamahiriya v Chad, Libya's Memorial (n 61) Part I, Ch I, section 2, entitled 'The sorts of considerations relevant to the resolution of such a dispute'; and Section 3, entitled 'The unique role of the Senoussi'. See also, Part III, Ch II, Section 3, entitled 'Senoussi Authoritv and Leadership in the Libva-Chad Borderlands' and 'The spread of the Senoussi Order into the Sahara and the Soudan'.

${ }^{64}$ Territorial Dispute (Libyan Arab Jamahiriya v Chad), Judgment of 3 February 1994 (n 58) 31, para 60.
} 
indigenous people, the Senoussi Order, the Ottoman Empire and Italy. ${ }^{65}$

In contrast, in the case of Kasikili/Sedudu Island (1999), ${ }^{66}$ the Court took into account the presence of indigenous peoples as proof of the exercise of territorial sovereignty by Namibia. ${ }^{67}$ In that case, an 1890 Anglo-German treaty had determined the 'main navigational channel' of the Chobe river as being the boundary line. Yet, the parties identified this channel of the river in a different way, with Botswana claiming it referred to the northern channel, while Namibia claimed it referred to the southern. Namibia equally claimed that, in the alternative, its right could be based on the doctrine of 'acquisitive prescription', ${ }^{68}$ in the sense of occupation, use and exercise of sovereign jurisdiction over the Kasikili Island. In order to prove it, Namibia referred to ' 10,000 Masubia people who lived on the island' 69 and followed a traditional way of life: the Masubia had their own patterns of farming and agriculture; maintained their own traditional systems of political, legal and judicial organization, including the existence of a Masubia Chief (Chikamatondo) $7^{70}$ and they also allegedly had a

\footnotetext{
${ }^{65}$ Ibid 38, para 75.

${ }^{66}$ Kasikili/Sedudu Island (Botswana v Namibia), Judgment of 13 December 1999, ICJ Reports 1999, 1045.

${ }^{67}$ Ibid 1092, para 71. Namibia argued that the people's presence was relevant not only because it 'corroborated the interpretation of the Treaty', but also because it gave rise to the application of the 'doctrines concerning acquisition of territory by prescription, acquiescence and recognition' and because it could prove it had continuous, long-standing, unopposed and peaceful possession of the Island since the termination of colonial rule (uti possidetis).

${ }^{68}$ Ibid 1093, para 72: ' subsequent conduct, which relates to an existing legal instrument, is opposed to prescription, the purpose of which is to destroy and to supplant a pre-existing title'.

${ }^{69}$ Botswana v Namibia, Memorial of the Republic of Namibia, Vol. 1, 28 February 1997, paras 14.2, 25 and 26ff.

${ }^{70}$ Ibid paras $230-1$.
} 
school and a place to bury their dead. ${ }^{71}$ The annual floods of the Zambezi for five or six months of the year were also a crucial point of the dispute, not only for the identification of the thalweg, ${ }^{72}$ but also for the presence of the people on the island. According to Namibia 'when the floods came, the village, including the chief's residence, his court and the school, moved to the nearby high ground at Kasika to await the next planting season'; ${ }^{73}$ whereas according to Botswana, 'this alleged occupation takes the form of the episodic agricultural activities on the Island of peasants from the village of Kasika, which is sited within Namibia. ${ }^{74}$ The Court was therefore bound to examine the extent to which the presence of the peoples on the island was relevant to the application of the 1890 treaty, ${ }^{75}$ as well as to acknowledge their nomadic way of life 'for purposes of agriculture and grazing' ${ }^{76}$ It also examined whether there were any links of allegiance between the Masubia and the Caprivi authorities, before concluding that the Masubia used the island intermittently according to the

\footnotetext{
${ }^{71}$ Ibid paras 209-17 (where Namibia presents 'corroborative evidence' as to the presence of the Masubia people). In paragraph 207, with respect to the dead, the memorial notes that 'nothing evidences the importance
} of the Island to the Masubia more strongly than the fact that many members of the community were buried on the Island. In this respect, the Island remains today an integral part of the cultural and social heritage of the people of the area'.

${ }^{72}$ Scientifically, the main navigational channel could be also defined as the one that carries the main proportion of the annual water flow. See Botswana v Namibia, Memorial of the Republic of Namibia (n 69) para 131 and Kasikili/Sedudu Island (Botswana v Namibia), Judgment of 13 December 1999 (n 66) 1064, para 29.

${ }^{73}$ Botswana v Namibia, Memorial of the Republic of Namibia (n 69) para 204.

${ }^{74}$ Botswana v Namibia, Counter-memorial of Botswana, Vol.1, November 1997, 1, para 4, and Kasikili/Sedudu Island (Botswana v Namibia), Judgment of 13 December 1999 (n 66) 1103, para 94. One of Botswana’s counter-claims therefore, consisted, inter alia, of stressing the sporadic nature of that use, as well as the fact that people living on the other side of the Chobe river also made use of the island.

${ }^{75}$ Kasikili/Sedudu Island (Botswana v Namibia), Judgment of 13 December 1999 (n 66) 1093-4, paras 71-4.

${ }^{76}$ Ibid, para 74. 
seasons and their needs, and that the maintenance of any forms of governance was not linked to any Namibian territorial claims. ${ }^{77}$ Even though no cultural claims of any peoples were directly involved in the judgment, the Courts considerations have paved the way for more substantial considerations of group rights, as discussed in Section III of this chapter.

\section{b) Indigenous peoples' cultural claims advanced by states in the context of the Court's advisory opinions}

In the context of advisory opinions, the Court has been somewhat more generous in recognising cultural aspects of collective claims (such as claims to self-determination). Yet, here again it has been cautious about making assumptions that extend its jurisdiction to questions which have not been asked. In contrast to the contentious cases, such as the West Africa cases discussed above ${ }^{78}$ the early opinions delivered by the Court have been both more substantiated in terms of the findings.

In the Western Sahara case the Mauritanian entity (the indigenous Sahrawi people living in Western Sahara already prior the Spanish colonisation and Moroccan occupation) was identified by its distinguishable nomadic way of life. ${ }^{79}$ Both Mauritania and Morocco in fact used the presence of indigenous peoples on the disputed territory and the subsequent legal ties developed in order to demonstrate their own territorial sovereignty. Mauritania's

\footnotetext{
${ }^{77}$ Ibid 1106, para 99.

${ }^{78}$ South West Africa, Judgment of 18 July 1966 (n 25) and accompanying text.

${ }^{79}$ Western Sahara, Advisory Opinion of 16 October 1975, ICJ Reports 1975, 12, para 87: 'Western Sahara (Rio de Oro and Sakiet El Hamra) is a territory having very special characteristics which, at the time of colonization by Spain, largely determined the way of life and social and political organization of the peoples inhabiting it' and para 88 describing their nomadic way of life and religious organization.
} 
argument in particular was that the people inhabiting the region were known as 'the Bilad Shinguitti, or Shinguitti country, which constituted a distinct human unit, characterized by a common language, way of life and religion', and placed emphasis 'on the special characteristics of the Saharan area and the nomadic existence of many of the tribes', going on to describe these characteristics in detail ${ }^{80}$ Morocco, likewise, described in detail the structure of the peoples, ${ }^{81}$ while only Spain, in its capacity as 'administering Power', argued that the peoples' cultural and religious practices were irrelevant and should not serve as a 'proof of any tie of allegiance.' 82 The Court gave a rather ambiguous answer to the question asked, ${ }^{83}$ partially aligning itself with Spain's argument. Yet, one may equally note that it adopted a rather dynamic approach, not only by accepting the peoples' rights to selfdetermination, but further by defining the characteristics of the Sahrawi people in a different way than the parties - as 'tribes or people having a social and political organization' who were actually the inhabitants of the disputed region. In the view of the Court, 'the nomadic peoples of the Shinguitti country should be considered as having [...] possessed rights'; and ' these rights constituted legal ties between the territory of Western Sahara and the 'Mauritanian entity'; and '[they] knew no frontier between the territories and were vital to the very maintenance of life in the region' ${ }^{84}$ Interestingly, the Court found that these ties 'did not involve territorial sovereignty or co-sovereignty or territorial inclusion in a legal entity' and that they were, generally, of a different character, ${ }^{85}$ implying that they could have been of a

\footnotetext{
${ }^{80}$ Ibid 38-60, see particularly para 132(b) and para 137.

${ }^{81}$ Ibid 43, para 94ff.

${ }^{82}$ Ibid 61 paras. $141-43$.

${ }^{83}$ Ibid 75, para 10, Declaration by Judge Gros.

${ }^{84}$ Ibid para 152.

${ }^{85}$ Ibid paras 150-51: 'In the opinion of the Court those ties did not involve territorial sovereignty or cosovereignty or territorial inclusion in a legal entity. In consequence, the 'geographical overlapping' drawn
} 
cultural or religious nature. Furthermore, even though the Court once again did not explicitly refer to the peoples' right to a traditional way of life, it still implicitly recognised it: 'The tribes, in their migrations, had grazing pastures, cultivated lands, and wells or water-holes in both territories, and their burial grounds in one or other territory. ${ }^{96}$

On the other hand in the Namibia opinion (1971) the Court recognized that 'the injured entity is a people' ${ }^{87}$ The Court, inspired perhaps by the then recently proclaimed United Nations declarations on self-determination, used human rights phraseology, stressing the precious need for the protection of indigenous peoples in the South African territory, ${ }^{88}$ particularly with respect to their right to non-discrimination. ${ }^{89}$

attention to by the two States had, in the Court's view, a different character from that envisaged in the statements quoted above.'

${ }^{86}$ Ibid 152.

${ }^{87}$ Legal Consequences for States of the Continued Presence of South Africa in Namibia (South West Africa) notwithstanding Security Council Resolution 276 (1970), Advisory Opinion of 21 June 1971, ICJ Reports 1971, 16 , para 127

${ }^{88}$ Ibid para 130: '...These measures establish limitations, exclusions or restrictions for the members of the indigenous population groups in respect of their participation in certain types of activities, fields of study or of training, labour or employment and also submit them to restrictions or exclusions of residence and movement in large parts of the Territory'

${ }^{89}$ Ibid para 131: 'to enforce distinctions, exclusions, restrictions and limitations exclusively based on grounds of race, colour, descent or national or ethnic origin which constitute aa denial of fundamental human rights is a flagrant violation of the purposes and principles of the Charter'. 
While until now the Court has been consequent in recognising peoples' right to selfdetermination, as well as to 'entrench' this right in international law, ${ }^{90}$ nonetheless in all cases in which the Court has considered this principle, it has avoided discussing its cultural aspects. For instance, in Paramilitary Activities in Nicaragua (1986), ${ }^{91}$ where the Court highlighted the freedom of states to choose their own 'political, social, economic and cultural' system, it did not substantively extend its analysis so as to explain the modalities of what a cultural system would mean. Even more strikingly, in the much anticipated Kosovo opinion, ${ }^{92}$ regarding Kosovo’s unilateral declaration of independence, it avoided considering the issue of culture, even though a number of participants had raised the question of cultural heritage and cultural determination in the round of negotiations. ${ }^{93}$ Likewise, in the advisory opinion regarding the Legal Consequences of the Construction of a Wall in the Occupied

\footnotetext{
${ }^{90}$ See Advisory Opinions on Namibia (n 87) and Western Sahara (n 79); also see Case Concerning East Timor (Portugal v Australia), Judgment of 30 June 1995, ICJ Reports 1995, 90, paras 102 and 28, where, additionally, self-determination is recognised as having an erga omnes character. See generally Gentian Zyberi, 'SelfDetermination Through the Lens of the International Court of Justice (2009) 56 Netherlands International Law Review 429, 450. See also Gentian Zyberi, 'The International Court of Justice and the Rights of Peoples and Minorities' in Christian Tams and James Sloan (eds), The Development of International Law by the International Court of Justice (OUP, 2013) 327, 339ff; Antonio Cassese, 'The International Court of Justice and the Rights of Peoples to Self-Determination' in Vaughan Lowe and Malgosia Fitzmaurice (eds), Fifty Years of the International Court of Justice. Essays in Honour of Sir Robert Jennings (CUP, 1996) 351. Also, more generally, see Shaw 'The Heritage of States' (n 46) 97.

${ }^{91}$ Case concerning Military and Paramilitary Activities in and against Nicaragua (Nicaragua $v$ United States of America), Judgment of 27 June 1986, ICJ Reports 1986, 14, para 263.

${ }^{92}$ Accordance with International Law of the Unilateral Declaration of Independence in Respect of Kosovo, Advisory Opinion of 22 July 2010, ICJ Reports 2010, 403.

${ }^{93}$ Ibid 431, para 67.
} 
Palestinian Territory, ${ }^{94}$ the Court made a number of valuable observations (including the recognition of applicability of the 1966 International Covenant on Economic, Social and Cultural Rights (ICESCR) ${ }^{95}$ and the 1989 Convention on the Rights of the Child (CRC) ${ }^{96}$ in the Occupied Palestinian Territory), yet it did not extend its analysis in a way so as to address the question of the Palestinian peoples' right to self-determination in the light of Palestinian culture, or the principle of cultural diversity and the need for neighbouring peoples to peacefully co-exist. ${ }^{97}$

\section{Towards a Proprio Motu Recognition of Collective Cultural Claims in the New}

\section{Millenium?}

The approach of the Court seems to be gradually transforming in the new millennium. One judgement of the Court issued in 2009, and two in early and late 2013 respectively, point to the enhancement, if not to a proprio motu protection of collective claims by the Court.

The first case is the Dispute Regarding Navigational and Related Rights,${ }^{98}$ in which the Court had to pronounce itself on the common boundary line between Costa Rica and Nicaragua and the navigational regime of the San Juan River. The Court in this case went much further than merely acknowledging the existence of inhabitants on the disputed territory, and it is

\footnotetext{
${ }^{94}$ Advisory Opinion of 9 July 2004, ICJ Reports 2004, 136.

${ }^{95}$ UNGA Res. 2200A(XXI), adopted on 16 December 1966, entered into force on 3 January 1976, 993 UNTS 3.

${ }^{96}$ UNGA Res. 45/25, adopted on 20 November 1989, entered into force on 2 September 1990, 1577 UNTS 3.

${ }^{97}$ Even though certain 'cultural nuances' may be already perceived; see Eleni Polymenopoulou, 'Cultural Rights in the Case-Law of the International Court of Justice ' (2014) 27 Leiden Journal of International Law 447, 452.

${ }^{98}$ Dispute regarding Navigational and Related Rights (Costa Rica v Nicaragua), Judgment of 13 July 2009, ICJ Reports 2009, 213.
} 
noteworthy that it did so in a case which did not, as such, concern peoples' rights, nor a territorial dispute, nor a claim to self-determination and the application of uti possidetis. Like in the Kasikili/Sedudu Island case, a colonial treaty existed since 1858, purporting to establish the exact boundary line on the south side of the river, in favour of Nicaragua. At the time of that treaty 'there was already a population inhabiting the Costa Rican side of the boundary thus defined'. ${ }^{99}$ However, the Court noted straight away that 'it cannot have been the intention of the authors of the 1858 Treaty to deprive the inhabitants of the Costa Rican bank of the river [..] of the right to use the river to the extent necessary to meet their essential requirements, even for activities of a non-commercial nature $[\ldots][\mathrm{T}]$ he parties must be presumed [... to] have intended to preserve for the Costa Ricans living on that bank a minimal right of navigation for the purposes of continuing to live a normal life in the villages along the river.' ${ }^{100}$ In its submissions to the Court, Costa Rica described the riparians' situation, and explained that their survival depended mostly on agriculture and fishing. ${ }^{101}$ It went on to state that since the filing of the application, Nicaragua had imposed navigational restrictions, including the prohibition of fishing for subsistence purposes on the River. ${ }^{102}$ Ultimately, one of the claims of Costa Rica, along with the violation of navigational rights, was the violation of 'the customary rights of fishing by residents of the Costa Rican bank of the River'. ${ }^{103}$

The Court upheld the customary fishing rights claim in such way that makes the judgement

\footnotetext{
${ }^{99}$ Ibid 246, para 78.

100 Ibid 246, para 79.

${ }^{101}$ Costa Rica v Nicaragua, Memorial of Costa Rica, 29 August 2006, 8, paras 1.07, 2.06.

${ }^{102}$ Ibid 36, para. 3.28.

${ }^{103}$ Ibid 49, para. 4.05, where Costa Rica explains that since the creation of Costa Rica it was expressly agreed that 'the navigation and fishing and other uses of the said river shall be common' and that 'ever since, the residents, both Costa Rican and Nicaraguan, along the banks of the San Juan have fished there for subsistence.'
} 
noteworthy for at least three reasons.

First, because of the Court's reasoning. Indeed, the Judges straightforwardly accept that the meaning of the word 'subsistence' excludes 'commercial or sport fishing', even though the parties 'have not attempted to define subsistence fishing (except by those exclusions) nor have they asked the Court to provide a definition'. ${ }^{104}$ The Court employed a fairly broad understanding of customary law, without formally looking into customary law requirements (state practice and opinio juris) ${ }^{105}$ and smoothly overcoming Nicaragua's argument that the 1858 Treaty did not provide for any fishing rights. ${ }^{106}$ It merely observed that 'subsistence fishing has without doubt occurred over a very long period' and that 'the practice, by its very nature, especially given the remoteness of the area and the small, thinly spread population, is not likely to be documented in any formal way in any official record'. 107

Second, because of the human rights phraseology used throughout the judgement, which demonstrates that the ICJ is now fully aware of the human rights developments, such as the increasingly positive protection afforded to indigenous peoples and their right to their

${ }^{104}$ Costa Rica v Nicaragua, Judgment of 13 July 2009 (n 98) 265, para 141.

105 The only qualification accepted by the Court to this customary right would be 'regulatory measures relating to fishing adopted for proper purposes, particularly for the protection of resources and the environment'; see ibid at 266, para 141, in fine. See also ibid 289, para 20 where, interestingly, Judge Scotnicov goes as far as opining that Nicaragua has no right to regulate this practice as such.

${ }^{106}$ Ibid 265, paras 140-44.

${ }^{107}$ Ibid 264, para 137. Notably, this absence of reference has been criticised by Judge Sepùlveda-Amor, who suggested that the Court should have followed a different ratio decidendi, referring rather to 'vested (or acquired) rights' rather than customary law, as observed by Simonetta Stirling-Zanda, 'Preserving Tradition that is Necessary to Exercising Essential Rights: Some Reflections on the ICJ Decision on Navigational Rights on the San Juan River' (2012) 14 International Community Law Review 195, 203. 
intangible heritage (including their rights to hunting and fishing). Similar findings are pointed out in the 2007 UNDRIP and a number of other instruments and human rights documents, including the views of the Human Rights Committee. ${ }^{108}$ This is particularly evident in the Court's observations with respect to the 'special relationship' of the riparian communities with the river, and when it considered 'the close connection between the claim relating to subsistence fishing and the Application'. ${ }^{109}$

Third, because of the judgement's absence of references to older ICJ law (case-law which could have been cited) or the PCIJ's case-law ${ }^{110}$ in order to establish the point of customary fishing rights stands out. This absence of reference was criticised by two concurring Judges. ${ }^{111}$ The fact that the Court did not cite that case law might, however, be significant, implying that such a 'human-centred' precedent with respect to the protection of individuals, and now groups, did not really exist previously, neither in PCIJ case law, nor in the older ICJ case-law of the 1950s and 1960s.

\footnotetext{
108 Polymenopoulou 'Cultural Rights' (n 97) 454; also see Stirling-Zanda 'Preserving Tradition' (n 107) 196, who argues 'de lege ferenda - that the Court's findings may suggest a move towards extending forms of international legal protection - indirectly and for functional purposes at least - to groups whose traditions are necessary to achieve sustainable development including access to essential social and economic rights.' See Chapters 5 by Kamrul Hossain and Chapter 10 by Kristin Hausler in this volume.

${ }^{109}$ Costa Rica v Nicaragua, Judgment of 13 July 2009 (n 98) 263, para 134-5.

${ }^{110}$ Some of the cases which could have been cited would include, for instance, German Settlers in Poland,
} Advisory Opinion of 10 September 1923, PCIJ Ser. B, No. 6; as well as early cases that reached the ICJ, such as the Asylum case (Colombia v Peru), Judgment of 20 November 1950, ICJ Reports 1950, 266; or the Right of Passage over Indian Territory (Portugal v India), Judgment of 12 April 1960, ICJ Reports 1960, 6.

${ }^{111}$ See Costa Rica v Nicaragua, Judgment of 13 July 2009 (n 98) concurring opinion of Judge Sépuldeva-Amor and concurring opinion of ad hoc Judge Guillaume who notes that 'private rights including property rights could be invoked'. This point is raised by Stirling-Zanda 'Preserving Tradition' (n 107) 204, fn 48. 
Consequently, it might legitimately be argued that this judgement somehow marks the beginning of an era of strong protection of collective human rights (in casu, cultural rights and the protection of a group's intangible heritage), and in a case where no explicit connection was made with either minority or indigenous rights.

The second judgment enhancing the protection of collective cultural rights, almost proprio motu, is the Frontier Dispute case (2013). ${ }^{112}$ This case could be considered a usual boundary dispute case, were it not for the presence of a number of indigenous peoples in the disputed area - nomads and Bellah people living in the Logomaten area. Hence, the importance of the case, like the Navigational rights case, resides precisely in the fact that the final beneficiaries of the outcome of the case are these two peoples. Niger raises the issue of their insufficient protection through the Treaty law applied in the specific case. Prior to independence, 'the boundary resulting from the 1927 texts raised problems for the nomadic populations, who were accustomed to travelling within a unitary area, which was now divided into two separate colonies'; ${ }^{113}$ while subsequent to independence they faced the 'problems of registration caused by certain differences in the regulations, particularly in regard to the taxation of livestock, which continued to encourage nomads to change their territory of origin'. ${ }^{114}$ It is remarkable that, in its consideration of the case, the ICJ, after having adjudicated the merits

\footnotetext{
${ }^{112}$ Frontier Dispute (Burkina Faso v Niger), Judgment of 16 April 2013, ICJ Reports 2013, 44.

${ }^{113}$ Burkina Faso v Niger, Memorial of the Republic of Niger, April 2011, 40, para 2.5 ('in order to retain their customary transhumant routes, or even to cultivate their croplands which overlapped the boundary, they had to pass from one Colony to the other').

114 Ibid 44, para 2.9.
} 
of the case, ${ }^{115}$ and without differentiating between the states' expressed the wish 'that each Party, in exercising its authority over the portion of the territory under its sovereignty, should have due regard to the needs of the populations concerned, in particular those of the nomadic or semi-nomadic populations, and to the necessity to overcome difficulties that may arise for them because of the frontier'. ${ }^{116}$ Even though, once again, the 'populations' are not specifically identified in the text of the judgement as indigenous (but merely as 'nomadic and semi-nomadic populations'), it is implied by this specific part of the judgement that the groups have a right to maintain their own cultural identity.

The third case is the Temple of Preah Vihear case - one of the few cases in which the disputed question before the World Court involved the protection of a cultural heritage. ${ }^{117}$

\footnotetext{
${ }^{115}$ That is, after having identified the frontier. See Burkina Faso v Niger, Judgment of 16 April 2013 (n 112) 48, para 111: 'The Court concludes that, in this section of the frontier, the line consists of a straight-line segment between the intersection of the Say parallel with the right bank of the River Sirba and the beginning of the Botou bend'.

116 Ibid para 112. Judge Antonio Cançado-Trindade makes these views of the Court much more explicit, making this new understanding of international law also much more explicit. See particularly his Concurring opinion, 'Chapter IX. The human factor and frontiers'.

${ }^{117}$ Another occasion would be, for example, the opinion that the Court gave regarding the use of nuclear weapons. In that case, one dissenting Judge, Judge Weeramantry, pointed to the need for protection of cultural monuments, particularly in light of the Hague Convention for the Protection of Cultural Property in the Event of Armed Conflict (adopted on 14 May 1954, entered into force on 7 August 1956, 249 UNTS 240) as well as the Convention Concerning the Protection of World Natural and Cultural Heritage (adopted on 16 November 1972, entered into force on 17 December 1975, 1037 UNTS 151). See Legality of the Threat or Use of Nuclear Weapons, Advisory Opinion of 8 July 1996, ICJ Reports 1996, 226, at 466-67 (section 3.j. para (iii) et seq.).
} 
The order issued in $2011^{118}$ and the judgement issued in December $2013^{119}$ both concerned the interpretation of another, older judgement $(1962)^{120}$ regarding military activities in the territory surrounding the Temple of Preah Vihear - a temple situated on top of a hill at the borderline between Cambodia and Thailand, formally under Cambodian sovereignty. In the 1962 judgement, the Court had merely noted that Thailand was under the obligation to retreat its military forces that were 'stationed by her at the Temple or in the vicinity on Cambodian territory. ${ }^{121}$ Cambodia disputed the meaning of the Court's findings and argued that this 'vicinity on Cambodian territory' referred in reality to Cambodian territory. As the dispute went on, Cambodia, in 2011 (that is, one year after the Temple was included in the UNESCO World Heritage List) decided to request the Court to reinterpret its 1962 judgment, as well as to indicate provisional measures in order to oblige the Thai forces to be retreated from the area of the Temple. The Court issued the provisional measures order as requested. In this order, it paid significant attention to the cultural value of the Temple and ruled that both parties this time should 'withdraw all military personnel currently present in the zone as thus defined' and 'refrain [...]also from any armed activity directed at the said zone', therefore implicitly recognizing the need of state cooperation for the protection of cultural heritage. ${ }^{122}$

${ }^{118}$ Request for Interpretation of the Judgment of 15 June 1962 in the Case Concerning the Temple of Preah Vihear (Cambodia v Thailand), Order of 18 July 2011 (request for the indication of provisional measures), ICJ Reports 2011, 537.

${ }^{119}$ Request for Interpretation of the Judgment of 15 June 1962 in the Case Concerning the Temple of Preah Vihear (Cambodia v Thailand), Judgement of 11 November 2013, ICJ Reports 2013, 281.

${ }^{120}$ Temple of Preah Vihear (Cambodia v Thailand), Judgment of 15 June 1962 (mertis), ICJ Reports 1962, 6, para 37.

${ }^{121}$ Naturally, the Court then had made no reference to the importance of the Temple as a cultural monument, even though the 1954 Hague Convention (n 117) and its First Protocol were already in force.

${ }^{122}$ Cambodia v Thailand, Order of 18 July 2011 (n 118) 554, para 63. Additionally, concurring Judge Trindade mentions specifically the UNESCO Convention, and the importance of the site as a site of cultural heritage, see 
Even more visibly in the 2013 judgement, while recognizing Cambodia's sovereignty over the whole territory including the 'vicinity', the Court made explicit reference to the temple as a site of 'religious and cultural significance for the peoples of the region'. ${ }^{123}$ Most notably, it ruled that both parties should comply not only with its previous order, but also with the World Heritage Convention, and that they should further 'co-operate between themselves and with the international community in the protection of the site as a world heritage'. ${ }^{124}$ With this judgement therefore, the Court paved the way to claim the right to a cultural heritage not only as an individual right, but much more significantly as a par excellence collective right: one that belongs to all humanity ${ }^{125}$ rather than to one state or the other.

\section{Conclusions}

Collective cultural claims are not addressed directly in ICJ jurisprudence since collectivities such as minorities or indigenous peoples do not have direct access to the Court. Hence, the jurisdiction of the Court to answer questions related to collective cultural claims largely depends on the states' reasons and intentions for bringing such issues to the attention of the

Separate Opinion of Judge Antonio Cançado Trindade, particularly Chapter 10, section 3, entitled 'Space and Time, and the Protection of Cultural and Spiritual World Heritage', ICJ Reports, 594-598, paras 82-95.

123 Cambodia v Thailand, Cambodia v Thailand), Judgement of 11 November 2013 (n 119) para 106.

124 Ibid.

${ }^{125}$ Likewise on this point, see Francesco Francioni, 'The Evolving Framework for the Protection of Cultural Heritage in International Law', in Silvia Borelli and Federico Lenzerini (eds), Cultural Heritage, Cultural Rights, Cultural Diversity: New Developments in International Law (Nijhoff, 2012) 3; and Francesco Francioni, 'The Human Dimension of International Cultural Heritage Law: An Introduction' (2011) 22 EJIL 9. See also Andrzej Jakubowski, State Succession in Cultural Property (OUP, 2015) 308. 
Court. Even when the states have raised collective claims issues, the issue of collective cultural rights (such as claims to cultural heritage, religion or education) were not an issue to be examined in terms of their benefit for individuals, or the members of groups, or the peoples themselves. Collective claims have been brought to the ICJ by states - usually with respect to their sovereignty over one territory or another (for example, Boundary between Cameroon and Nigeria; Territorial Dispute). Furthermore, in absence of an explicit jurisdictional basis, the Court has not used its competence to elaborate collective cultural claims issues further in the context of advisory opinions (for example, Kosovo, Legal Consequences of the Construction of a Wall) - with the exception perhaps only of the Western Sahara case, issued in the context of colonisation. It seems however, that in the new millennium the Court has made substantial progress in taking into account collectivities' human rights claims, finally overcoming its long-standing reputation of being a 'conservative body'. ${ }^{126}$ Even though the approach of the Court is still rather cautious in terms of explicitly recognising cultural aspects of collective claims, two observations regarding the Court's current practice may lead to positive outcomes in the future. First, the Court now employs a more 'flexible' understanding of international law, which includes consideration of human rights instruments and states' human rights obligations, including in their cultural dimension (for example, Legal Consequences of the Construction of a Wall). Secondly, the Court has taken steps towards recognising peoples' rights to their cultural identity and to their intangible heritage (Navigational Rights). Furthermore, in two 2013 cases it has highlighted the importance of culture, in its collective dimension, and imposed obligations to respect

\footnotetext{
${ }^{126}$ See, for example, Francesco Francioni, 'International "Soft Law”: a Contemporary Assessment' in Vaughan Lowe and Malgosia Fitzmaurice (eds), Fifty Years of the International Court of Justice (CUP, 1996), 169; W. Michael Reisman, 'The Supervisory Jurisdiction of the International Court of Justice: International Arbitration and International Adjudication' (1996) 258 RCADI 9, 233ff. It should be noted, however, that the Court had issued much fewer cases during that time.
} 
cultural rights to all states involved in the dispute (Frontier Dispute; Temple of Preah Vihear). It remains to be seen to what extent this newly-developed approach will gain recognition and become more explicit, allowing the Court to attain a central role in the vindication of peoples' claims. 